\title{
Biomass accumulation, plant biometrics and fruit production of watermelon according to changes in source/drain relations
}

\author{
Hamurábi Anízio Lins', José Ricardo Tavares de Albuquerque², \\ Roberto Cleiton Fernandes de Queiroga ${ }^{2}$, Francisco Vanies da Silva Sá ${ }^{3 *}$, \\ 'Federal University of Campina Grande, Pombal, PB, Brazil \\ ${ }^{2}$ Federal Rural University of Pernambuco, PE, Brazil \\ ${ }^{3}$ Federal Rural University of Semiarid, Mossoró, RN, Brazi \\ *Corresponding author, e-mail: vanies_agronomia@hotmail.com
}

Auderlan de Macena Pereira', Ariano Barreto da Silva', Emanoela Pereira de Paiva ${ }^{3}$

\begin{abstract}
The objective of this study was to evaluate the accumulation of biomass, plant biometrics and production of watermelon fruit submitted to changes in source and drain relations. The experiment was conducted in the experimental area of the CCTA/UFCG, PB, Brazil, during the period from September to December, 2013. Seed of the cultivar "Crimson Sweet" were used and the treatments were allocated in $2 \times 4$ split plots, with four replications. Plots consisted of plants grown with different number of fruits ( 1 and 2 ) and the subplots with dominant stem pruning in different growing seasons $(25,30,35$ and 40 days after transplanting - DAT). Growth characteristics were evaluated. The modifications induced in watermelons by dominant stem pruning and fruit thinning provided changes in photoassimilate partitions and plant production. The modifications induced in watermelons by dominant stem pruning and fruit thinning provided changes in biomass accumulation, biometrics and the watermelon production of fruits. The thinning of plant's drain (fruit) resulted in more dry mass accumulation of leaves when comparing to fruit, providing a higher total dry mass. Plants grown with two fruits presented the highest harvest index and the highest production, with reduced fruit size. The stem pruning of seedlings at 40 days after transplanting promoted a higher growth and production of watermelon fruits.
\end{abstract}

Keywords: Citrullus lanatus, plant handling, pruning, fruit thinning

Partição de fotoassimilados, biometria e produção de frutos de melancieira sob alterações na relação fonte/dreno

\section{Resumo}

Objetivou-se avaliar o acúmulo de fitomassa e a biometria de frutos de melancieira quando submetidas a alterações na relação fonte e o dreno. O experimento foi realizado na área experimental do CCTA/UFCG, durante o período de setembro de 2012 a dezembro de 2013. Para isso, utilizaram-se sementes da cultivar "Crimson Sweet". Os tratamentos foram alocados em parcelas subdivididas $2 \times 4$, com quatro repetições. As parcelas constaram da condução da planta com diferente número de frutos ( 1 e 2) e nas subparcelas da poda da haste dominante em diferentes épocas de cultivo $(25,30,35$ e 40 dias após o transplante - DAT). Foram avaliadas características de crescimento. As modificações induzidas na planta da melancieira por meio de podas da haste dominante e do raleio de frutos proporcionaram alterações no acúmulo de biomassa, na biometria e na produção de frutos de melancia. A diminuição do dreno preferencial na planta (fruto) resultou na elevação das massas secas da folha em relação ao fruto, e desta forma, proporcionando maior massa seca total. As plantas conduzidas com dois frutos obtiveram o maior índice de colheita e a maior produção, com frutos de tamanho reduzido. Realização da poda da haste dominante $\square$ aos 40 dias após o transplantio das mudas promoveu incrementos no crescimento e produção dos frutos de melancieira.

Palavras-chave: Citrullus lanatus, manejo da planta, poda, raleio de frutos 


\section{Introduction}

Watermelon (Citrullus lanatus) is a fruit belonging to the Cucurbitaceae family, with a cosmopolitan distribution. In Brazil, the crop is important, providing the production of plants with high yield and with high quality of harvested fruits (Lins et al., 2013). In 2011 , this crop presented a production of 1946.912 tons in 92.996 hectares of planted area. The Northeast region of Brazil is the largest producer, comprising $35.7 \%$ of the harvested area and $29.2 \%$ of the Brazilian total production (IBGE, 2015).

The adoption of a new production system requires knowledge of crops and can determine the most appropriate management for different areas with different conditions. It is necessary to know the relations that can influence the plant functioning and then understand the way in which all these relations are linked with each other, in order to result in a final production. Thus, there are data indicating that the management of the relation between source and drain, through changes in planting density and the number of fruits per plant, may have different outcomes on the growth of fruit and vegetative organs compared to vegetables that produce smaller fruits (Duarte et al., 2008; Guimarães et al., 2008; Silva et al., 2011).

In watermelons, fruits are considered preferred drains after pollination when compared to growth. Thus, the increase in the number of fixed fruits leads to a competition for assimilates among drains and leads to a decrease in individual fruit weight (Silva et al., 2011 ; Lins et al., 2013). Thereby, the source/drain relation must be considered as a coordinate system, in which, considering plants with a limited supply, the number of drains is often reduced through loss of flowers and/or fruits. On the other hand, considering plants with limited drains, the development and/or photosynthetic activity of leaves can also be changed (Marcelis et al., 2004; Duarte et al., 2008).

Watermelon is a plant that enables various methods of managing regarding the relationship between source and drain. Changes in sources and drains influence growth, production and fruit quality at harvest (Lins ef al., 2013). Duarte \& Peil (2010), studying melons, point out the reduction of the source and drain relation due to the appearance of a new fruit competing, observed more with remaining fruits than with vegetative organs. Thus, the control of the number of growing fruits and the ideal time for pruning are considered useful measures to control the source/drain relation and the balance of assimilates among vegetative organs and fruits in a profitable harvest (Peil \& Gálvez, 2005; Duarte et al., 2008; Silva et al., 2011). Thus it is possible that the control of source/drain on watermelon plant can improve the photoassimilates distribution in the plant, reducing the energy necessary to shoot growth, directing it to the growth of the fruit.

The objective of this study was to evaluate the accumulation of biomass, biometrics and production of watermelon fruit when submitted to changes in source and drain relations.

\section{Material and Methods}

The experiment was conducted in the experimental area of the Centre for Science and Agrifood Technology at the Federal University of Campina Grande, Pombal County, Paraiba State, Brazil, during the period from September to December, 2013. Local geographical

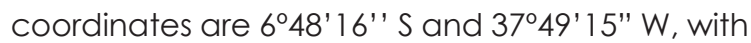
average altitude of $144 \mathrm{~m}$. The region's climate, according to the Köppen climate classification, adapted to Brazil, is BSh, a hot and dry semi-arid climate with an average rainfall of $750 \mathrm{~mm}_{\text {year }}{ }^{-1}$ and annual average evaporation of $2,000 \mathrm{~mm}$. The soil of the area is Alfisols Udalf (United States Department of Agriculture, 2014) (Table 1).

The seeds were sown in September 2012 with "Crimson Sweet" cultivar seeds, packaged in 128-cell polystyrene trays containing commercial agricultural substrate suitable for the production of vegetable seedlings. The trays were placed in a greenhouse and irrigated twice a day until the transplant, which occurred within 15 days after sowing.

Soil preparation was made by plowing and harrowing. Five rows spaced with $3.0 \mathrm{~m}$ were used and the fertilization at planting was made with organic manure (20 t ha-1, cattle manure) (Table 1) and $5 \mathrm{~g}$ per plant with chemical NPK 10-10-10 fertilizer, manually incorporated 15 days before transplant. 
Table 1. Chemical characterization of the soil cultivation area with watermelon.

\begin{tabular}{|c|c|c|c|c|c|c|c|c|c|c|c|c|}
\hline & $\mathrm{pH}$ & EC & $\mathrm{N}$ & P & $\mathrm{K}^{+}$ & $\mathrm{Ca}^{+2}$ & $\mathrm{Mg}^{+2}$ & $\mathrm{Na}^{+}$ & $\mathrm{H}^{+}+\mathrm{Al}^{+3}$ & CEC & \multirow{2}{*}{$\begin{array}{l}\text { PES } \\
-\%-\end{array}$} & \multirow{2}{*}{$\begin{array}{l}\text { M.O } \\
g k^{-1}\end{array}$} \\
\hline & $\mathrm{CaCl}_{2}$ & $\mathrm{dS} \mathrm{m}^{-1}$ & $\%$ & \multicolumn{2}{|c|}{$\mathrm{mg} \mathrm{dm}^{-3}$} & & - & nolc 0 & $7^{-3}$ & & & \\
\hline$S$ & 7.16 & 0.01 & 0.11 & 4.0 & 0.16 & 6.80 & 4.30 & 0.09 & 0.00 & 11,35 & 0.79 & 19 \\
\hline$E$ & 7.75 & 6.65 & 564.0 & 24.64 & 7.70 & 15.90 & 9.18 & 8.15 & 0.00 & 40.93 & 14.19 & 48.5 \\
\hline
\end{tabular}

The cover fertilization was made daily via fertigation, starting three days after seedlings transplanting. Urea, monoammonium phosphate and potassium chloride at dosages of 60, 120 and $80 \mathrm{~kg} \mathrm{ha}^{-1}$ of $\mathrm{N}, \mathrm{P}_{2} \mathrm{O}_{5}$ e $\mathrm{K}_{2} \mathrm{O}$ (Ribeiro et al., 1999) were used as sources of nitrogen, phosphorus and potassium, respectively. In each fertigation, the following percentages of each nutrient were respectively applied: $1 \mathrm{st}=5.0 \% \mathrm{~N}$ and $7.0 \% \mathrm{~K}_{2} \mathrm{O}$; 2nd $=8.0 \% \mathrm{~N}$ and $10.0 \% \mathrm{~K}_{2} \mathrm{O} ; 3 \mathrm{rd}=10.0 \% \mathrm{~N}$ and $8.0 \% \mathrm{~K}_{2} \mathrm{O} ; 4$ th, 5 th and 6 th $=20.0 \% \mathrm{~N}$ and $18.0 \%$ $\mathrm{K}_{2} \mathrm{O} ; 7 \mathrm{th}=7.0 \% \mathrm{~N}$ and $7.0 \% \mathrm{~K}_{2} \mathrm{O} ; 8$ th and $9 \mathrm{th}=5.0 \%$ $\mathrm{N}$ and $7.0 \% \mathrm{~K}_{2} \mathrm{O}, 70 \mathrm{~kg} \cdot \mathrm{ha}^{-1}$ of magnesium sulfate, $70 \mathrm{~kg}$ of calcium sulphate and $10 \mathrm{~kg} \mathrm{ha}^{-1}$ of boric acid were also applied together with irrigation water. Daily irrigation was performed by dripping, using drippers with $1.0 \mathrm{~m}$ spacing, with a flow rate of 2.70 L.h $^{-1}$. Water need was measured with the aid of a tensiometer. Ploughing and pest control, when necessary, were performed in accordance to the recommendation for the crop.

The treatments were allocated in a randomized block design with subplots and four replications. Plots consisted of different number of fruits per plant ( 1 and 2) and the subplots of dominant stem pruning in different growing seasons $(25,30,35$ and 40 days after transplanting - DAT). The plot consisted of a row $16.0 \mathrm{~m}$ long and a subplot with $4.0 \mathrm{~m}$ long, containing four plants. The spacing was $3.0 \times 1.0 \mathrm{~m}$. The plants were managed according to the suggested treatments. The fruits one and two were fixed in secondary branches from the 10th node of the dominant stem. The pruning of the dominant stem occurred in the mentioned seasons, leaving the side branches free to grow. During the crop cycle, when necessary, manual ploughing and pest control were made with fungicides and insecticides registered for the crop. Harvesting began at 70 days after sowing.

After the harvest of the fruits and the vegetative parts of the plants, the following characteristics were evaluated, by sampling the productive area of each plot and the fruits with firmness, color uniformity, healthy skin, without deformations, wilting, cracks, signs of rotting, pest attacks or mechanical damage were considered commercial.

After the selection of commercial fruits, they were taken to a food analysis laboratory in order to determine longitudinal and transversal diameter $(\mathrm{cm})$ using a digital caliper. Mesocarp thickness $(\mathrm{cm})$ was obtained by readings of the equatorial region after a longitudinal cut using a digital caliper. The average production per plant ( $\mathrm{kg} \mathrm{plant}^{-1}$ ) was measured with a digital scale with a precision of $0.01 \mathrm{~g}$.

At the end of the experiment, the plants were used to determine photoassimilate partitions. The plants were partitioned in stems, leaves and fruit. The collected material was placed in paper bags and placed to dry in a forced-air oven at $65^{\circ} \mathrm{C}$ for 72 hours. With this data, the dry mass of leaves and stem (g plant ${ }^{-1}$ ), fruits (g fruit ${ }^{-1}$ ), total dry mass (g plant ${ }^{-1}$ ) and harvest index (\%) were measured by the ratio of fruit dry mass and total plant dry mass.

Data were submitted to analysis of variance using the SAEG 9.0 software. When significant, the Tukey's mean test was carried out considering the number of fruits, and a polynomial regression analysis was realized considering the pruning times factor, both with $5 \%$ of probability.

\section{Results and Discussion}

It was observed that plants with only one fruit had the highest accumulation of leaf dry mass (6\%) when compared to plants with two fruits. However, for the variables fruit dry mass (FDM), total dry mass (TDM) and harvest index $(\mathrm{HI})$, the best results were obtained in plants grown with two fruits, obtaining a superiority of 9.0, 8.0 and $7.0 \%$, respectively, when compared to plants with only one fruit. It was also observed that a change in the number of fruits did not significantly affected stem dry mass (Table 2). 
This may be related to a lower draining power of plants with only one fruit, stimulating vegetative growth and thus the highest photoassimilate directed to leaves. However, in plants with two fruits, where there is a greater draining power to the source, there is the greatest directing of photoassimilates to the fruit and thereby the reduction of the growth of source organs (leaves). This reduction of a drain present in watermelons (fruit) resulted in an increased vegetative growth, reducing total and fruit weight, besides compromising the harvest index.

Table 2. Mean values of the dry mass of leaves (DML) and stem (DMS), fruits (DMF), total dry mass (DMT) and harvest index (HI) of watermelon plants according to the number of fruits per plant.

\begin{tabular}{cccccc}
\hline \multirow{2}{*}{ Number of fruits } & DML & DMS & DMF & DMT & HI \\
\hline 1 & $137.93 \mathrm{a}$ & $61.24 \mathrm{a}$ & $454.48 \mathrm{~b}$ & $644.90 \mathrm{~b}$ & $0.68 \mathrm{~b}$ \\
\hline 2 & $129.18 \mathrm{~b}$ & $56.36 \mathrm{a}$ & $500.41 \mathrm{a}$ & $694.71 \mathrm{a}$ & $0.73 \mathrm{a}$ \\
\hline $\mathrm{CV}(\%)$ & 33.27 & 30.03 & 24.29 & 20.33 & 10.67 \\
\hline
\end{tabular}

In columns, means followed by the same letter do not differ according to Tukey's test at $5 \%$ of probability.

Queiroga et al. (2009), studying the partition of assimilates in greenhouse-cultivated melons with different numbers of leaves and fruits, observed that the draining power, represented by fruits, was evidenced by a greater fruit dry mass and by stem dry mass, particularly in plants with two fruits. As the fruit of watermelon is the preferred drain after pollination, it is expected that fruit dry mass contribute with a major proportion to total dry mass accumulation in the plant. Possibly, this happens because of the sum of the dry mass of the two fruits, which overlaps fruit dry matter individually, which also contributed to a higher harvest index in plants with two fruits. This was also observed by Queiroga et al. (2008) with melons, where plants with two fruits obtained a higher allocation of photoassimilates in the fruits, resulting in a higher total dry matter.

It is important to noteworthy that, for watermelons, the emergence of a new fruit has a direct effect on the source organs (leaves). This diverges from the results of Duarte \& Peil (2010), in an experiment with melons, in which the reduction of the source and drain relation due to the appearance of a new fruit competes more with remaining fruits than with vegetative organs.

As for the pruning of the dominant stem, there was a quadratic behavior for LDM and SDM variables, where the highest biomass accumulation occurred at 34 days after pruning of the dominant stem (DAPDS), obtaining the estimated maximum values of 140 and $66 \mathrm{~g} \mathrm{plant}^{-1}$, respectively (Figure $1 \mathrm{~A}$ and $\mathrm{B}$ ). This behavior was probably due to the breaking of the apical dominance at an early period. This stimulates the emission of a greater number of lateral branches, contributing to the raising of LDM and SDM accumulation. This was also verified by Santi et al. (2013), evaluating the performance and the management of Japanese cucumber grown in a protected environment.

However, a late pruning favored fruit and total dry mass and the harvest index, being the best results observed at 40,37 and 40 DAPDS, with $526 \mathrm{~g} \mathrm{fruit}^{-1}, 723 \mathrm{~g} \mathrm{plant}^{-1}$ and $73 \%$, respectively (Figure 1C, D e E). As the beginning of the fruiting period was between the 28th to the 40th day after transplantation, there was a strong competition between the source and the drain. Leaf and stem dry mass values were thus higher. With the pruning done at approximately 40 DAPDS, it resulted in a higher dry mass accumulation in the fruit probably due to lower leaf and stem dry matter values provided by a greater competition between the source and the drain in this period, contributing to the higher harvest index. Thus, as the fruit is the commercial product of watermelons, it is interesting that there is a greater mass accumulation in it, fact verified with late pruning at 40 days after seedling's transplanting.

Similar results were verified by Melo et al. (2014) in net melons, in which the late pruning promoted the highest accumulation of fruit and total dry mass. With tomato, Logendra et al. (2001) did not observed significant differences for the harvest index with a pruning being performed with 0,1 and 2 leaves above the bunches.

The greatest longitudinal and transverse diameters and the greatest thickness of the flesh 
were found when the plant was managed with only one fruit. A superiority of 16, 22 and $13 \%$ was verified comparing to plants managed with two fruits, respectively (Table 3). The highest values for longitudinal and transverse diameters and

A

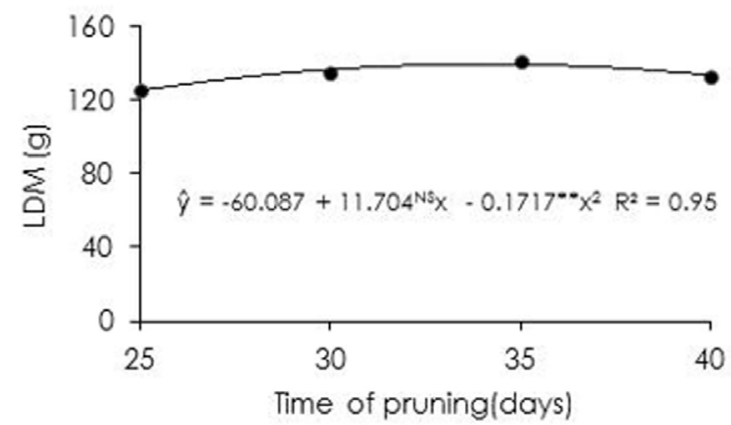

$\mathrm{C}$



flesh thickness in plants managed with only one fruit can be mainly attributed to a reduced competition between the source and the drain in plants with only one fruit, which results in a greater photoassimilate supply for fruit's growth.

B

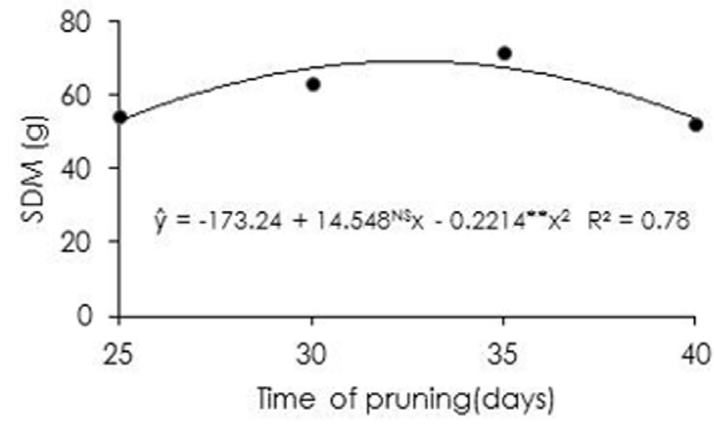

D

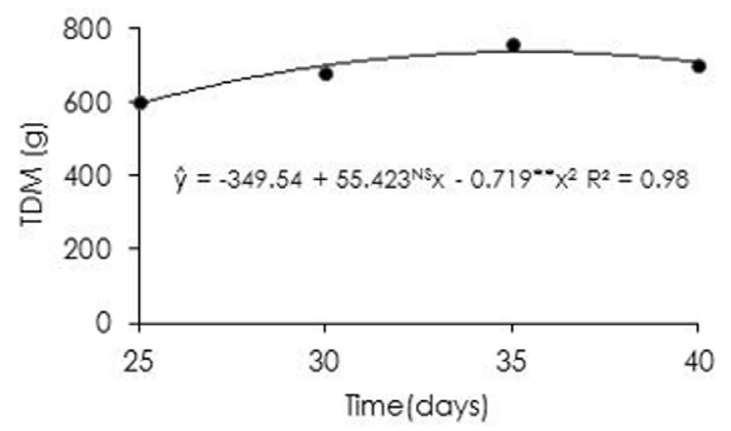

E

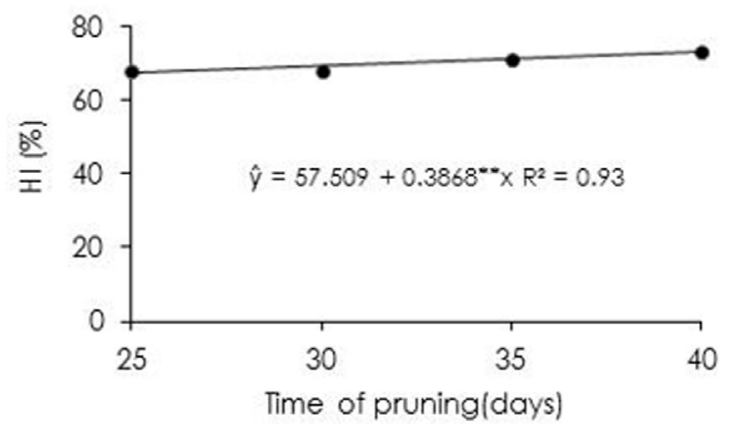

Figure 1. Dry mass of leaves (LDM) (A), stem (SDM) (B), fruits (FDM) (C), total (TDM) (D) and harvest index (HI) (E) of watermelon fruits depending on the time of pruning of the dominant stem and the number of fruits per plant.

Table 3. Average values of fruit transverse diameter (TDF), longitudinal diameter of the fruit (LDF), flesh thickness (PT) and production per plant (P/P) of watermelon fruits according to the number of fruits per plant.

\begin{tabular}{|c|c|c|c|c|}
\hline \multirow{2}{*}{ Number of fruits } & TDF & LDF & PT & $\mathrm{P} / \mathrm{P}$ \\
\hline & \multicolumn{3}{|c|}{  } & $\mathrm{kg} \mathrm{plant}^{-1}$ \\
\hline 1 & $21.24 \mathrm{a}$ & $22.24 a$ & $17.65 a$ & $4.34 \mathrm{~b}$ \\
\hline 2 & $17.88 \mathrm{~b}$ & $18.88 \mathrm{~b}$ & $15.32 \mathrm{~b}$ & $6.12 a$ \\
\hline CV (\%) & 6.65 & 7.24 & 6.60 & 14.03 \\
\hline
\end{tabular}

Queiroga et al. (2009 evaluating the number and the position of melon fruits on the plant, observed higher values for fruit diameter, both transverse and longitudinal, when the plant was managed with only one fruit. These authors state that the reduction in the number of fruits per 
plant provides an increase in the source: drain ratio, resulting in more photoassimilates available for crop's growth. Moreira et al. (2012) observed a similar behavior of 'Pokan' tangerine plants, where the most intensive thinning resulted in the greatest longitudinal and transverse fruit growth.

However, there was a higher production

in plants with two fruits, $29 \%$ higher than the production obtained by plants with only one fruit (Table 3). This was expected, as the presence of two fruits increases the draining power in the source, corroborating to the results referring to partitions of photoassimilates (LDM, SDM and FDM) (Table 2). There were, on average, fruits with 4.34 and $3.06 \mathrm{~kg}$ in plants with one and with two fruits, respectively. Thus, the control of the source: drain relation is a viable alternative to the management of fruits destined for internal markets, in this case, the largest fruits obtained

A

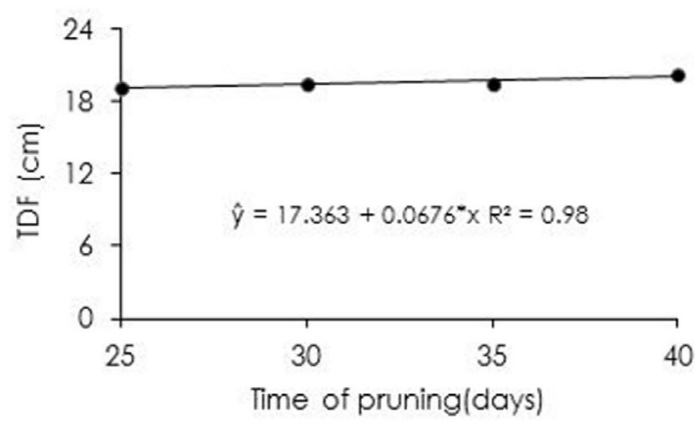

C

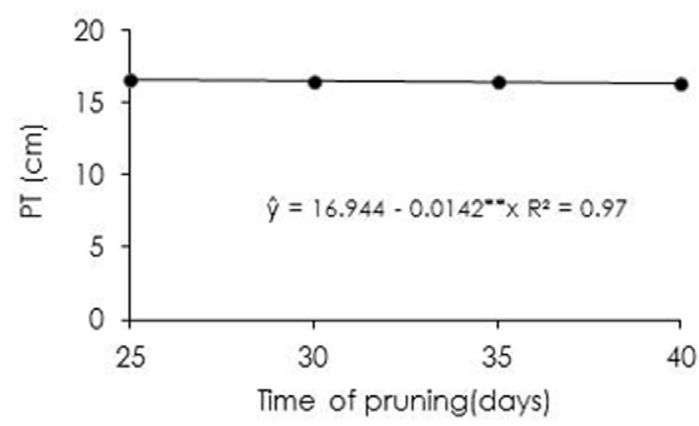

by managing plants with a single fruit; in case of external markets, smaller fruits with plants managed with two fruits. Peil et al. (2014) obtained similar results with tomato plants, where plants with more fruits achieved the highest production per plant. However, they had smaller fruits when compared to plants with fewer fruits. These results were similar to those obtained for fruit dry mass and harvest index.

For the pruning of the dominant stem, a linear increase response was found regarding longitudinal and transversal fruit diameter, with an increase of 1.05 and $1.20 \mathrm{~cm}$, being the pruning performed at 25 and 40 DAPDS, respectively (Figure $2 A$ and $B$ ). This fact was also verified on Y/P. A late pruning provided the highest production per plant, with a $0.09 \mathrm{~kg}$ unit increase in P/P due to the increase of days to perform pruning of the dominant stem (Figure 2D).

B

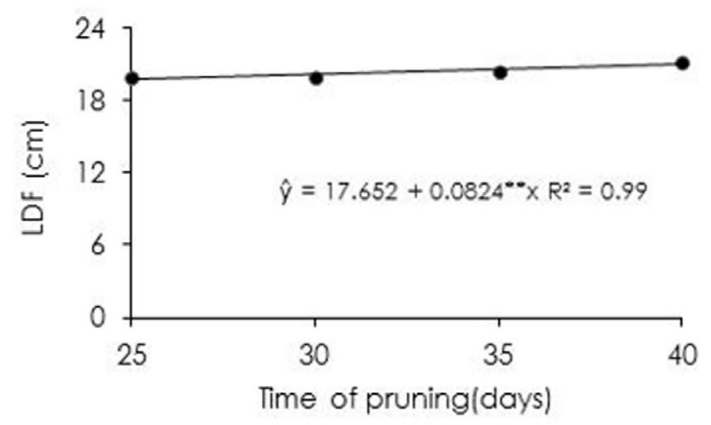

D



* And $* *=$ significant at 1 and $5 \%$, respectivelly.

Figure 2. Fruit transverse diameter (TDF) (A), fruit longitudinal diameter (LDF) (B), flesh thickness (PT) (C) and production per plant $(P / P)(D)$ of watermelon fruit depending on the time of pruning of the dominant stem and the number of fruits per plant.

Pruning, when performed in a late period, resulted in the emission of side branches when the drain was in an accelerated growth phase. Thus, young leaves contributed to the increase of plant leaf area, balancing the source and drain relation. This may also cause the delay of leaf senescence, resulting in a greater leaf area available per fruit. However, Freitas et al. (2014), evaluating the management of pruning in pumpkin plants, did not found significant effects on any variable studied, pointing out that the management of pruning presents divergent 
results between Cucurbitaceae.

However, considering the thickness of the mesocarp, the response decreased linearly, with a $0.2 \mathrm{~cm}$ reduction, when the pruning was performed at 40 DAPDS (Figure 2C). Nevertheless, this behavior did not affected the plant production, considering that reductions in flesh thickness are insignificant when compared to increases in transverse and longitudinal diameters. Silva et al. (2012), evaluating the thickness of mini watermelon flesh under different pruning methods, also observed reductions in flesh thickness depending on the performing of late pruning (after the 8th node).

Generally the attainment of pruning before 35 days adversely affected the accumulation of biomass, biometric features and the production of melon plants (Figures 1 and 2). This behavior may be related to the reduced emission of leaves by plants due to the early pruning, since the leaves are the organs responsible for the production of assimilates (the organs sources) (Marcelis et al., 2004; Duarte et al., 2008). Thus the plants with a limited supply consequently had lower biomass accumulation, lower growth and fruit production, due to the competition between fruit and vegetative growth, compared to those in which the late pruning was performed.

\section{Conclusions}

The modifications induced in watermelons by dominant stem pruning and fruit thinning provided changes in accumulation of biomass, biometrics and in the production of watermelon fruits.

The thinning of plant's drain (fruit) resulted in the elevation of leaves dry mass in relation to the fruit, providing a higher total dry mass.

Plants grown with two fruits had the highest harvest index and the highest production, with reduced fruit size.

The dominant stem pruning of seedlings at 40 days after transplanting promoted a higher growth and production of watermelon fruits.

\section{References}

Duarte ,T.S., Peil, R.M.N., Montezano, E.M. 2008. Crescimento de frutos de meloeiro sob diferentes relações fonte: dreno. Horticultura Brasileira 27:
342-347.

Duarte, T.S., Peil, R.M.N. 2010. Relações fonte:dreno e crescimento vegetativo do meloeiro. Horticultura Brasileira 28: 271-276.

Freitas, P.G.N., Claudio, M.T.R., Tavares, A.E.B., Magro, F.O., Cardoso, A.I.I., Bardiviesso, E.M. 2014. Poda apical para produção de frutos e sementes de abóbora. Revista Agro@mbiente On-line 8: 230-237.

Guimarães, M.A., Silva, D.J.H., Fontes, P.C.R., Mattedi, A.P. 2008. Produtividade e sabor dos frutos de tomate do grupo salada em função de podas. Bioscience Journal 24: 32-38.

IBGE. Instituto Brasileiro de Geografia e Estatística. 2015. <http://www.ibge.gov.br/ Access:May 1st, 2015>.

Lins, H.A., Queiroga, R.C.F., Pereira, A.M., Silva, G.D., Albuquerque, J.R.T. 2013. Produção e qualidade de frutos de melancia em função de alterações na relação fonte-dreno. Revista Verde Agroecologia e Desenvolvimento Sustentável 8: 143-149.

Logendra, L.S., Gianfagna, T.J., Janes, H.W. 2001. Using mini-rockwool blocks as growing media for limited-cluster tomato production. Hortechnology 11: 175-179.

Marcelis, L.M.F., Heuvelink, L.R., Hofman-Eijer, B., Baker, J.D., Xue, L.B. 2004. Flower and fruit abortion in sweet pepper in relation to source and sink strenght. Journal Experimental of Botany 55: 2261- 2268.

Melo, D.M., Charlo, H.C.O., Castoldi, R., Braz. L.T. 2014. Dinâmica do crescimento do meloeiro rendilhado 'Fantasy' cultivado em substrato sob ambiente protegido. Biotemas, 27: 19-29.

Moreira, R.A., Ramos, J.D., Silva, F.O.R., Costa, A.C. 2012. Qualidade de tangerinas 'Ponkan' em função da regularidade no raleio químico. Pesquisa Agropecuária Tropical 42: 303-309.

Peil, R.M.N., Albuquerque Neto, A.A.R., Rombaldi, C.V. 2014. Densidade de plantio e genótipos de tomateiro cereja em sistema fechado de cultivo em substrato. Horticultura Brasileira 32: 234-240.

Peil, R.M.N., Gálvez, J.L. 2005. Reparto de materia seca como factor determinante de la producción de las hortalizas de fruto cultivadas en invernadero. Revista Brasileira de Agrociência 11:05-11.

Queiroga, R.C.F., Puiatti, M., Fontes, P.C.R., Cecon, P.R. 2009. Características de frutos de meloeiro variando número e posição de frutos na planta. Horticultura Brasileira 27: 23-29. 
Lins et al. (2016) / Biomass accumulation, plant biometrics and fruit...

Queiroga, R.C.F., Puiatti, M., Fontes, P.C.R., Cecon, P.R. 2008. Produtividade e qualidade de frutos de meloeiro cultivado em ambiente protegido variando número de frutos e de folhas por planta. Horticultura Brasileira 26: 115-120.

Ribeiro A.C., Guimarães P.T.P., Alvarez V.H. 1999. Recomendação para o uso de corretivos e fertilizantes em Minas Gerais. UFV, Viçosa, Brasil. $359 \mathrm{p}$.

Santi, A., Scaramuzza, W.L.M.P., Soares, D.M.J., Scaramuzza, J.F., Dallacort, R., Krause, W., Tieppo, R.C. 2013. Desempenho e orientação do crescimento do pepino japonês em ambiente protegido. Horticultura Brasileira 31: 649-653.

Silva, A.C., Leonel, S., Souza, A.P., Vasconcellos, M.A.S., Rodrigues, J.D., Ducatti, C. 2011 . Alocação de fotoassimilados marcados e relação fontedreno em figueiras $\mathrm{cr}$. Roxo de Valinhos. 1. Relação fonte e dreno. Revista Brasileira de Ciências Agrárias 6: 409-418.

Silva, C.M., Gusmão, S.A.L., Silva, G.B., Lima, G.C. 2012. Efeito da poda de ramos laterais na qualidade e produção de frutos de mini melancia em cultivo hidropônico NFT. Revista Brasileira de Agrociência 18: 304-314.

United States Department of Agriculture. 2014. Keys to Soil Taxonomy. 12 ed. Washington, USA. 353p. 